УДК 633.11 “321”: 631.82:631.5

(C) 2016

Каленська С. М., доктор сільськогосподарських наук, Шутий О. I., аспірант

(науковий керівник - доктор сільськогосподарських наук С. М. Каленська)

Національний університет біоресурсів і природокористування України

\title{
ФОРМУВАННЯ ПРОДУКТИВНОСТІ ТА ЯКОСТІ ПШЕНИЦІ ТВЕРДОЇ ЯРОЇ ЗАЛЕЖНО ВІД МІНЕРАЛЬНОГО ЖИВЛЕННЯ У ПРАВОБЕРЕЖНОМУ ЛІСОСТЕПУ УКРАЇНИ
}

\section{Рецензент - доктор сільськогосподарських наук О. А. Цюк}

\begin{abstract}
Визначено вплив сорту, особливості мінерального живлення пшениці твердої ярої в Правобережному Лісостепу України. Встановлено, щуо застосування позакореневого підживлення на фоні основного удобрення має позитивний вплив на продуктивність та якість досліджуваних сортів. Обгрунтовано роль системи живлення рослин, яка дає змогу керувати формуванням зернової продуктивності посівів пшениці твердої ярої. Встановлено, щзо оптимізація режиму живлення забезпечує більш повне розкриття ресурсного потенціалу рослин, за рахунок чого зростає врожайність.
\end{abstract}

Ключові слова: пшениця тверда яра, продуктивність, якість, система удобрення, підживлення.

Постановка проблеми. Збільшення виробництва зерна у світі є нагальною проблемою сьогодення $[1,15]$. Потреба у забезпеченні населення продуктами харчування, тварин - якісними кормами, промисловості - сировиною - зростає постійно, роблячи сільськогосподарському виробництву нові виклики [2].

Забезпечення населення України високоякісними продуктами харчування, підвищення ефективності галузі рослинництва вимагає перегляду структури посівних площ зі введенням у структуру не лише «рентабельних культур», а й культур, які забезпечують у першу чергу повноцінне харчування людини, - пшениця тверда, тритикале, просо, гречка, нут, сочевиця та інші культури, які у виробництві називають «нішовими», напевно через те, що вони знайшли свою «нішу» або займають незначну посівну площу $[1,14]$.

Пшениця тверда традиційно вирощувалася в південних регіонах України, переважно озимі форми, а поява нових сортів пшениці твердої ярої обумовлює можливість вирощування іiі і в інших регіонах. В умовах північної частини Правобережного Лісостепу України вирощування пшениці твердої озимої є досить ризикованим, так як вона характеризується низькою зимостійкістю, що обумовлює підвищену зацікав- леність до вирощування у цих умовах пшениці твердої ярої. Нині є досить багато зареєстрованих сортів пшениці твердої ярої і для реалізації генетичного потенціалу цих сортів необхідно знати їх реакцію на екологічні та технологічні чинники вирощування у певних умовах. В Україні питанням селекції і насінництва пшениці твердої ярої значну увагу приділяють в Інституті рослинництва ім. В. Я. Юр'єва, Миронівському Інституті пшениць ім. Ремесла, ННЦ «Інститут землеробства НААН» $[3,10]$.

Зернові культури, які розвиваються за ярим типом, поступаються озимим зерновим за урожайністю, проте вони, як правило, мають значну перевагу щодо якості зерна. Власне завдяки підвищеній якості зерна ярим формам приділяється значна увага $[4,13]$. Зерно пшениці твердої ярої характеризується особливим хімічним складом, що дає змогу використовувати його для виробництва продуктів харчування, які неможливо виробляти з зерна інших зернових культур без втрати їхньої якості $[5,11]$. Зерно пшениці твердої ярої $\epsilon$ цінною зерновою культурою, яка за продовольчим значенням та масштабами виробництва повинна займати щільне місце. Зазвичай зерно пшениці твердої (Triticumdurum Desf.) використовується для виготовлення макаронних виробів, круп, а також може виступати, як поліпшувач під час випікання хліба $[6,8]$.

Однією 3 проблем непопулярності пшениці ярої на ланах нашої держави $є$ іiї низька урожайність: за даними Державного комітету статистики України середня урожайність за останні роки знаходиться на рівні 2,5 т/га, тому основні напрями у вирішенні та збільшенні урожайності $€$ за рахунок аналізу та удосконалення елементів технології вирощування, розкриття генетичного потенціалу сучасних сортів, які адаптовані до конкретних грунтово-кліматичних зон, дає перспективи виробництва зерна даної культури, що $\epsilon$ надзвичайно важливим з огляду на те, що більша частина продукції, яка виробляється із зерна 


\section{СІЛЬСЬКЕ ГОСПОДАРСТВО. РОСЛИННИЦТВО}

пшениці твердої в Україні імпортується і налагодження власного ринку зерна і насіння твердих сортів $є$ надзвичайно актуальним.

Аналіз останніх досліджень і публікацій, у яких започатковано розв'язання проблеми. Одним із ключових та впливових чинників, які впливають на урожайність та якість є елементи живлення, форми їхніх сполук та способи застосування. Збілышення врожайності та покращання якості зерна належить мінеральному живленню за рахунок збільшення в грунті доступних елементів. Добрива сприяють формуванню більшої площі та ефективності функціонування асиміляційного апарату, зростанню та нагромадженню сухої речовини, збільшенню продуктивності фотосинтезу, підвищенню продуктивності рослин [7].

Головною умовою одержання високоякісного зерна є дотримання рекомендованої для кожного виду пшениці сортової агротехніки. Зі спеціальних агротехнічних прийомів, які направлені на покращання якості зерна, - одним $є$ позакореневе підживлення $[1,2,6,9]$.

Ефективність підживлень підтверджено результатами досліджень Інституту рослинництва ім. В. Я. Юр'єва під час вивчення впливу різних доз і строків внесення азотних добрив на якість зерна пшениці ярої. Важливим показником якості зерна є вміст білка, натура та скловидність. На думку багатьох вчених, у пшениці твердої ярої вищий вміст білка, висока скловидність, що $\epsilon$ цінним для виготовлення високоякісних макаронних виробів. Порівняно із м'якою пше- ницею, вимоги до стандартів якості пшениці твердої, зокрема за вмістом білка та натури, є жорсткішими [12].

Мета дослідження є оптимізація системи живлення рослин сортів пшениці твердої ярої за рахунок використання макро- та мікроелементів 3 метою отримання високоякісного зерна за одночасного підвищення врожайності.

Матеріали і методика дослідження. Дослідження проводились у 2012-2014 рр. у стаціонарному досліді кафедри рослинництва в ВП НУБіП України «Агрономічна дослідна станція» (с. Пшеничне Васильківського району Київської області). Схема досліду передбачала визначення впливу основного удобрення i позакореневого підживлення рослин азотом та мікроелементами на урожайність і якість зерна сортів пшениці твердої ярої. Грунт дослідної ділянки - чорнозем типовий малогумусний, середньосуглинковий. Вміст гумусу в орному шарі 4,3-4,5 \%, забезпеченість грунту легкогідролізованим азотом - середнє, рухомим фосфором - вище середнього, обмінного калію - середнє. Попередник - соя. Площа елементарної ділянки - $60 \mathrm{~m}^{2}$, облікової $30 \mathrm{~m}^{2}$, повторність досліду - чотириразова, розміщення варіантів систематичне (табл. 1).

Підживлення рослин проводили відповідно до схеми досліду, використовуючи різні за складом добрива «Росток»: «Росток» Зерновий - норма внесення 2,5 л/га; «Росток» Макро - 1 л/га та «Росток» Плодоношення - 2,5 л/га.

\section{1. Схема досліду}

\begin{tabular}{|c|c|c|c|c|c|c|c|}
\hline \multirow{3}{*}{$\begin{array}{c}\text { Сорт } \\
\text { чинник A }\end{array}$} & \multicolumn{7}{|c|}{$\begin{array}{c}\text { Система удобрення, кг/га д.р. } \\
\text { чинник В }\end{array}$} \\
\hline & \multirow{2}{*}{ 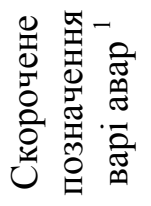 } & \multicolumn{3}{|c|}{ Основне удобрення } & \multicolumn{3}{|c|}{ Підживлення ${ }^{2}$} \\
\hline & & $\mathrm{P}_{2} \mathrm{O}_{5}$ & $\mathrm{~K}_{2} \mathrm{O}$ & $\mathrm{N}$ & IV & VI & $X$ \\
\hline \multirow{2}{*}{ Харківська - 27(st) } & В1 (к1) & \multicolumn{6}{|c|}{ Без добрив (контроль 1) } \\
\hline & B2 & 75 & 75 & 50 & - & - & - \\
\hline \multirow{2}{*}{ Харківська - 41} & В3 (к2 ) & 75 & 75 & 75 & - & - & - \\
\hline & B4 & 75 & 75 & 100 & - & - & - \\
\hline \multirow[t]{2}{*}{ Жізель } & B5 & 75 & 75 & 75 & $\mathrm{~N} 12,5$ & $\mathrm{~N} 12,5$ & - \\
\hline & B6 & 75 & 75 & 75 & N12,5+P3, PM. & N12,5+PП, PM. & - \\
\hline \multirow[t]{2}{*}{ Ізольда } & B7 & 75 & 75 & 75 & $\mathrm{~N} 8,3$ & $\mathrm{~N} 8,3$ & $\mathrm{~N} 8,3$ \\
\hline & B8 & 75 & 75 & 75 & N8,3+P3, PM. & N8,3+PП, PM & $\mathrm{N} 8,3+\mathrm{P} 3$ \\
\hline
\end{tabular}

Примітки: ${ }^{1}$ к1 - контроль 1 (без добрив); к2 - контроль 2 (рекомендована система удобрення для виробництва);

${ }^{2}$ Р. 3. - «Росток» Зерновий; Р. М. - «Росток» Макро; Р. П. - «Росток» Плодоношення; N - азот. 
СІЛЬСЬКЕ ГОСПОДАРСТВО. РОСЛИННИЦТВО

2. Характеристика комплексних водорозчинних добрив «Росток», г/л

\begin{tabular}{|c|c|c|c|c|c|c|c|c|c|c|c|}
\hline \multirow{2}{*}{ Марка } & \multicolumn{10}{c|}{ Вміст елемента } \\
\cline { 2 - 14 } & $\mathrm{N}$ & $\mathrm{P}_{2} \mathrm{O}_{5}$ & $\mathrm{~K}_{2} \mathrm{O}$ & $\mathrm{MgO}$ & $\mathrm{SO}_{3}$ & $\mathrm{Fe}$ & $\mathrm{Mn}$ & $\mathrm{B}$ & $\mathrm{Zn}$ & $\mathrm{Cu}$ & $\mathrm{Mo}$ \\
\hline «Росток» Зерновий & 80 & - & - & 51 & 37 & 3,6 & 12 & 2 & 2 & 9 & 0,05 \\
\hline «Росток» Макро & 60 & 120 & 60 & 0,2 & 10 & 1,4 & 1 & 0,2 & 2,2 & 2,5 & 0,055 \\
\hline $\begin{array}{c}\text { «Росток» } \\
\text { Плодоношення }\end{array}$ & - & 100 & 200 & - & 5 & 0,5 & 2 & 0,75 & 0,6 & 0,6 & 0,05 \\
\hline
\end{tabular}

Фосфорні та калійні добрива використовували у вигляді гранульованого суперфосфату та калійної солі, які вносили згідно зі схемою досліду під основний обробіток грунту, азотні добрива навесні під передпосівну культивацію. У позакореневе підживлення за етапами органогенезу вносили карбамід та мікродобриво «Росток» (табл. 2).

Мікродобриво «РОСТОК» містить макро- та мікроелементів на хелатній основі, які застосовуються для передпосівної обробки насіння та позакореневого підживлення рослин та в системах фертигації. Як відомо, для нормального розвитку рослин необхідно не тільки макро-, а й мікроелементи. Найважливішими мікроелементами для зернових культур є $\mathrm{Cu}, \mathrm{MgO}, \mathrm{Fe}, \mathrm{Zn}$, які містяться в мікродобриві «Росток» Зерновий та Макро. Застосування даного добрива у IV етап органегонезу позитивно впливає на проходження процесів фотосинтезу, дихання, синтезу білків, вуглеводів та азотного обміну, забезпечує синтез хлорофілу, формування генеративних органів, підвищує посухостійкість, жаростійкість, стійкість до ураження хворобами. «Росток» Макро, який у своєму складі додатково має макроелементи $\mathrm{P}_{2} \mathrm{O}_{5}$ та $\mathrm{K}_{2} \mathrm{O}$, відповідає на даному етапі за фотосинтез, підвищує гідратацію колоїдів цитоплазми, іії водоутримуючу здатність і проникність, сприяє росту кореневої системи, покращує кущення, впливає на кількість колосків у суцвітті.

Застосування мікродобрив «Росток» Плодоношення та Макро на VI етапі органогенезу відіграє важливу функцію у синтезі вуглеводів, їх перетворенні і транспортуванні, а також в окислювальновідновлювальних процесах, білковому і нуклеїновому обміні, синтезі стимуляторів росту; зумовлює активність ферментів; покращує осмотичні процеси; сприяє синтезу хлорофілу та асиміляції $\mathrm{CO}_{2}$; зменшує редукції квіток; підвищує посухостійкість і солестійкість рослин.

Застосування мікродобрив «Росток» Зерновий на $\mathrm{X}$ етапі органогенезу сприяє посиленню синтезу АТФ, включення азоту в синтез білків, сприяє збільшенню розміру та маси зернівки.

Основне значення мікроелементів полягає у підвищенні активності ферментів, які каталізу- ють біохімічні процеси. Мікроелементи, які входять до складу вітамінів, ферментів, активують ïх роботу, беруть участь в азотних і вуглеводних обмінах рослин, в окисно-відновних процесах, підсилюють процес фотосинтезу. Крім того, вони підвищують проникність клітинних мембран, що впливає на надходження іонів у рослину, на структуру і фізіологічні функції рибосом. Під їхньою дією підвищується стійкість рослин проти грибкових, вірусних і бактеріальних хвороб, несприятливих умов зовнішнього середовища.

Результати дослідження. Урожайність пшениці твердої ярої суттєво змінювалася за роками проведення досліджень, залежно від системи удобрення, та відслідковувалась сортова реакція рослин на застосування різних доз макро- та мікроелементів - від 1,43 до 5,20 т/га в розрізі всіх досліджуваних чинників.

Нами для проведення досліджень щодо встановлення потенціалу пшениці твердої ярої, іiі адаптивності та ефективності застосування системи удобрення були вибрані сорти селекції Інституту рослинництва ім. Юр'єва - Харківська 27 та Харківська 41; Миронівського Інституту пшениці ім. В. М. Ремесло - Жізель та Ізольда.

Ефективність удобрення визначається комплексом абіотичних і технологічних чинників. Ефективність підживлень значно зростала із використанням комплексних мікродобрив «Росток». Проведено низку досліджень із вивчення доцільності застосування мікродобрив для підвищення врожайності та якості зерна пшениці ярої (табл. 3). Встановлено доцільність поєднання азотних добрив та мікродобрива «Росток», які за значно меншої дози за ефектом були рівноцінними мінеральним азотним формам добрив. Так, у сорті Харківська 27 застосування мінеральних добрив мало позитивний вплив на формування урожайності, що варіювала залежно від варіанту удобрення від 2,67 до 3,84 т/га за урожайності у контрольному варіанті (без добрив) 1,61 т/га. Застосування азотних добрив у підживлення за етапами органогенезу сприяло зростанню урожайності від 0,37 до 0,66 т/га порівняно 3 варіантом у випадку внесення цієї ж норми добрив у передпосівну культивацію. 
СІЛЬСЬКЕ ГОСПОДАРСТВО. РОСЛИННИЦТВО

3. Урожсайність пшениці твердої ярої, $\mathrm{m} / 2 a$

\begin{tabular}{|c|c|c|c|c|c|c|c|c|c|c|c|c|}
\hline \multirow{3}{*}{$\begin{array}{l}\text { Варіант } \\
\text { досліду }\end{array}$} & \multicolumn{6}{|c|}{ сорт Харківська - 27} & \multicolumn{6}{|c|}{ сорт Харківська - 41} \\
\hline & \multirow[t]{2}{*}{2012} & \multirow[t]{2}{*}{2013} & \multirow[t]{2}{*}{2014} & \multirow[t]{2}{*}{ Середнє } & \multicolumn{2}{|c|}{$\begin{array}{c}\text { Приріст, } \\
\text { т/га } \\
\end{array}$} & \multirow[t]{2}{*}{2012} & \multirow[t]{2}{*}{2013} & \multirow[t]{2}{*}{2014} & \multirow[t]{2}{*}{ Середнє } & \multicolumn{2}{|c|}{$\begin{array}{c}\text { Приріст, } \\
\text { т/га } \\
\end{array}$} \\
\hline & & & & & к1 & к2 & & & & & к1 & к2 \\
\hline В1 (к1) & 1,68 & 1,43 & 1,61 & 1,61 & - & - & 2,09 & 1,87 & 2,18 & 2,05 & - & - \\
\hline B2 & 2,76 & 2,28 & 2,67 & 2,67 & 1,06 & - & 2,95 & 2,17 & 3,19 & 2,77 & 0,72 & - \\
\hline B3 (к2) & 3,25 & 2,96 & 3,19 & 3,19 & 1,58 & - & 3,39 & 2,73 & 3,72 & 3,28 & 1,24 & - \\
\hline B4 & 3,34 & 3,27 & 3,36 & 3,36 & 1,75 & - & 3,54 & 2,85 & 3,90 & 3,43 & 1,39 & - \\
\hline B5 & 3,76 & 3,42 & 3,63 & 3,63 & - & 0,45 & 4,28 & 3,69 & 4,16 & 4,04 & - & 0,76 \\
\hline B6 & 3,98 & 3,49 & 3,84 & 3,84 & - & 0,66 & 4,42 & 3,85 & 4,30 & 4,19 & - & 0,91 \\
\hline B7 & 3,57 & 3,50 & 3,56 & 3,56 & - & 0,37 & 3,93 & 3,76 & 4,48 & 4,06 & - & 0,78 \\
\hline B8 & 3,71 & 3,66 & 3,71 & 3,71 & - & 0,53 & 4,05 & 3,81 & 4,61 & 4,16 & - & 0,87 \\
\hline \multicolumn{7}{|c|}{ сорт Жізель } & \multicolumn{6}{|c|}{ сорт Ізольда } \\
\hline B1 (к1) & 2,13 & 1,83 & 2,50 & 2,15 & - & - & 1,98 & 1,59 & 2,37 & 1,98 & - & - \\
\hline B2 & 3,48 & 3,53 & 3,75 & 3,59 & 1,43 & - & 3,43 & 2,62 & 3,37 & 3,14 & 1,16 & - \\
\hline B3 (к2) & 4,19 & 4,21 & 4,27 & 4,22 & 2,07 & - & 3,89 & 3,31 & 3,73 & 3,64 & 1,66 & - \\
\hline B4 & 4,01 & 4,19 & 4,02 & 4,07 & 1,92 & - & 3,91 & 3,31 & 3,93 & 3,72 & 1,74 & - \\
\hline B5 & 4,62 & 4,65 & 5,10 & 4,79 & - & 0,57 & 4,73 & 3,46 & 4,73 & 4,30 & - & 66 \\
\hline B6 & 4,72 & 4,79 & 5,20 & 4,90 & - & 0,68 & 4,82 & 3,85 & 4,95 & 4,54 & - & 0,89 \\
\hline B7 & 4,84 & 4,73 & 4,96 & 4,84 & - & 0,62 & 4,34 & 3,94 & 4,45 & 4,24 & - & 0,6 \\
\hline B8 & 4,93 & 4,82 & 5,11 & 4,95 & - & 0,73 & 4,42 & 4,05 & 4,59 & 4,35 & - & 0,71 \\
\hline \multicolumn{7}{|c|}{$\begin{array}{c}H P_{05} \text { для чинника «сорт» } \\
H P_{05} \text { для чинника «удобрення» } \\
\text { HIP }_{05} \text { для чинника «погодні умови» }\end{array}$} & \multicolumn{6}{|c|}{$\begin{array}{r}0,49 \\
0,84 \\
0,47\end{array}$} \\
\hline
\end{tabular}

Аналогічна закономірність спостерігалася у сорті Харківська 41 - урожайність була на рівні від 2,77 до 4,19 т/га, що на 0,72-2,14 т/га вище за контроль (без добрив). Найвищу урожайність було отримано у варіанті В6, яка становила 4,19 т/га.

У сорту пшениці твердої Ізольда удобрення та проведення підживлення мікродобривом «Росток» мало позитивний вплив на формування урожайності. Показники урожайності змінювалися залежно від варіантів удобрення від 3,14 до 4,35 т/га, за урожайності у контрольному варіанті - 1,98 т/га.

Найвищу врожайність серед досліджуваних сортів було отримано у сорті Жізель у варіанті В8 і становила 4,95 т/га, що на 2,86 т/га більше порівняно $з$ контролем. Отже, на основі одержаних нами результатів можна стверджувати, що позакореневе підживлення водорозчинними добривами 3 мікроелементами значною мірою мало вплив на підвищення врожайності пшениці твердої ярої.
Отже, позакореневі підживлення - вагомий резерв для повного розкриття ресурсного потенціалу зернової продуктивності посівів пшениці твердої ярої нових сортів інтенсивного типу Ізольда та Жізель.

Диференційоване застосування у підживлення азоту та мікроелементів крім управління формуванням урожайності в першу чергу спрямовано на покращання якості зерна. Якість зерна пшениці твердої $є$ визначальним чинником ціни зерна та ефективності технології вирощування культури загалом. Для одержання якісних та високих урожаїв велике значення має застосування азотних добрив у оптимальні строки. Потреба рослин пшениці у азоті пов'язана з особливістю мінерального живлення у фазу наливу зерна, у даний період вона засвоює близько $30 \%$ азоту від загальної кількості за вегетацію. Тому важливе значення має позакореневе підживлення пшениці як фактор економічного і раціонального використання добрив. 


\section{4. Вміст білка в зерні пшениці твердої ярої залежно від системи удобрення (середнс 3а 2012-2014 pp.)}

\begin{tabular}{|c|c|c|c|c|}
\hline \multirow{2}{*}{ Варіант удобрення } & \multicolumn{4}{|c|}{ Сорт } \\
\hline & Харківська - 27 & Харківська - 41 & Жізель & Ізольда \\
\hline B1 & 12,1 & 12,2 & 11,0 & 11,4 \\
\hline B2 & 13,1 & 13,3 & 11,5 & 12,1 \\
\hline B3 & 14,0 & 14,2 & 12,2 & 13,3 \\
\hline B4 & 14,1 & 14,5 & 13,2 & 14,1 \\
\hline B5 & 14,3 & 14,8 & 14,1 & 15,0 \\
\hline B6 & 14,6 & 15,2 & 14,3 & 15,4 \\
\hline B7 & 15,0 & 15,0 & 14,1 & 15,2 \\
\hline B8 & 15,4 & 15,5 & 14,4 & 15,6 \\
\hline \multicolumn{4}{|c|}{$\begin{array}{c}\text { HІР }_{05} \text { для чинника «сорт» } \\
\text { HІР }_{05} \text { для чинника «удобрення» }\end{array}$} & $\begin{array}{l}0,6 \\
1,3\end{array}$ \\
\hline
\end{tabular}

Одним 3 основних показників, який характеризує якість зерна пшениці твердої, є вміст білка в зерні. Проведені дослідження свідчать про те, що якість зерна значною мірою визначається системою удобрення (табл. 4).

Усі досліджувані варіанти підживлень забезпечували істотне збільшення вмісту клейковини в зерні, порівняно з контролем. Вміст білка в зерні пшениці сорту Ізольда в середньому за роки досліджень змінювався від 10,4 до 15,6 \%; Харківська 27 - від 10,1 до 15,4 \%, Жізель - від 10,0 - 14,4 \%; Харківська 41 - 10,2-15,5\%. За рівнем ефективності у збільшенні вмісту білка у зерні - варіант $\mathrm{N}_{75} \mathrm{P}_{75} \mathrm{~K}_{75} 3$ підживленням

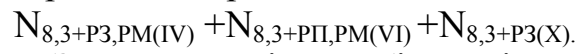

Зерно за вмістом білка відносилося до 1-5 класів якості. Застосування азотних підживлень сприяло суттєвому підвищенню вмісту білка у

\section{БІБЛІОГРАФІЯ}

1. Антал Т.В. Продуктивність пшениці ярої твердої залежно від елементів технологій вирощування в Правобережному Лісостепу України : автореф. дис. на здобуття наук. ступеня к.с.-г.н. / Т. В. Антал. - К. : НУБіП, 2010. - 22 с.

2. Андрійченко Л. В. Шляхи підвищення врожайності та якості зерна пшениці ярої твердої на півдні України / Л.В.Андрійченко // Вісник аграрної науки Причорномор'я. - 2006. - №33. Випуск 1. - С. 33-38.

3. Влияние минеральных удобрений на урожайность и качество зерна яровой пшеницы в Казахстанском Приаралье / [Жайлыбай К. Н., Токтамысов А. М., Сагиндыкова А. С., Нурмаш Н. К.] // Агрохимия. - 2005. - №11. - С. 43-48.

4. Каленська С. М. Агроекологічні аспекти застосування добрив в технологіях вирощування тритикале / С. М. Каленська // Зб. наук. праць зерні пшениці твердої ярої та інших показників якості. Управління формуванням якості за рахунок диференційованого внесення мінеральних добрив дає можливість отримувати зерно 1-2 класу якості.

Висновок. Дослідженнями встановлено провідну роль системи живлення рослин, яка дає можливість управляти формуванням зернової продуктивності посівів пшениці твердої ярої. Оптимізація режиму живлення забезпечує більш повне розкриття ресурсного потенціалу рослин, за рахунок чого зростає врожайність. Встановлено, що нові високопродуктивні сорти - Жізель та Ізольда - розкривають свій зерновий потенціал на варіантах із позакореневим підживленням по етапах органогенезу на фоні основного удобрення $\mathrm{N}_{75} \mathrm{P}_{75} \mathrm{~K}_{75}$.

Ін-ту землеробства УААН. - К., 1997. - Вип. 1. C. 68-70.

5. Каленська С. М. Ефективність застосування біогенних металів та біоактивних препаратів при вирощуванні сої [Електронний ресурс] / С. М. Каленська, К. Г. Лопатько, Н. В. Новицька // Наукові доповіді Наукового вісника НУБіП. 2011. - №5 (27). - Режим доступу : http://www. nbuv.gov.ua/e-journals/Nd/2011_5/11ksm.pdf.

6. Каленська С. М., Плакса В. М. Вплив норм висіву, мінеральних та водорозчинних добрив на ріст і розвиток тритикале ярого / С. М. Каленська, В. М. Плакса // Науковий вісник НУБіП України. 2009. - №141. - С. 123-129.

7. Каленська С. М. Вплив мінеральних добрив та ретардантного захисту на урожайність ячменю ярого пивоварного / С. М. Каленська, Р. Холодченко, Б. Токар // Агробіологія. - Випуск 1 
(117). - 2015. - C. 56-58.

8. Каленська С. М. Формування показників структури врожаю пшениці твердої ярої залежно від елементів технології вирощування / С. М. Каленська, О. І. Шутий // Вісник Сумського нац. аграрного університету. - Серія «Агрономія і біологія». - 2015. - Вип. 3 (29). - С. 170-173.

9. Точное сельское хозяйство / [Шпаар Д., Захаренко А., Каленская С., Якушев В. и др.]. Санкт-Петербург : Пушкин, 2009. - 397 с.

10. Управління продуктивністю посівів пшениці твердої ярої в Лівобережному та Північному Лісостепу України / [Рожков А. О., Пузік В. К., Каленська С. М., Пузік Л. М., Бобро М. А., Чигрин О. В., Антал Т. В.]. - Х. : Майдан, 2015. $432 \mathrm{c}$.

11. Возобновляемые растительные ресурсы / [Шпаар Д., Драгер Д., Каленская С., Рахметов Д.]. Санкт-Петербург : Пушкин, 2006. - Т. 1. - 415 с.

12. Кормовые культуры. Производство, уборка, консервирование и использование грубых кормов / [Шпаар Д., Гибелхаузен Г., Каленская С. М., Дрегер Д., Петриченко В.Ф. и др.]. - М. : ИД ООО «ДЛВ Агродело», 2009. - Т. 1. - 464 с.

13. Committee of World Food Security [Електронний ресурс]. - Режим доступу : www.yara.ua/ crop-nutrition/crops/wheat/key-facts/world-wheatproduction.

14. Franzen D. W. Fertilizing hard red spring wheat and durum [Електронний ресурс] / D. W. Franzen // NDSU extension service, 2014. - 8 p. - Режим доступу : https://www.ag.ndsu.edu/pubs/plantsci/ soilfert/sf712.pdf.

15. Impact of weather conditions and fertilizers on growth and yield potential of cereal [Kalens'ka S. M., Kovalenko R., Kachura I., Novits'ka N.] : Internationale wissenschaftliche Konferenzam 18 und 19 Oktober 2012 in Bernburg-Strenzfeld [«Nährstoff- und Wasserversorgung der Pflazenbestande unter den Bedingungen der Klimaerwarmung»]. - 2014. - ISBN : 978-3-86011-069-0. P. 45-49. 